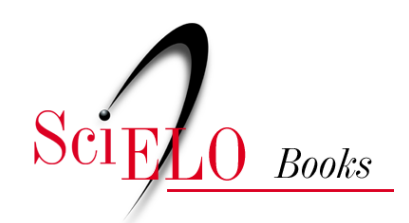

\title{
Território Federal do Iguaçu
}

\author{
José Carlos Radin \\ Gentil Corazza
}

\section{SciELO Books / SciELO Livros / SciELO Libros}

RADIN, J.C., and CORAZZA, G. Território Federal do Iguaçu. In: Dicionário histórico-social do Oeste catarinense [online]. Chapecó: Editora UFFS, 2018, pp. 138-139. ISBN: 978-85-64905-65-8. https://doi.org/10.7476/9788564905658.0034.

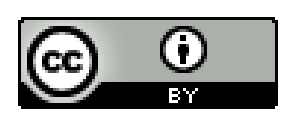

All the contents of this work, except where otherwise noted, is licensed under a Creative Commons Attribution 4.0 International license.

Todo o conteúdo deste trabalho, exceto quando houver ressalva, é publicado sob a licença Creative Commons Atribição $\underline{4.0}$.

Todo el contenido de esta obra, excepto donde se indique lo contrario, está bajo licencia de la licencia $\underline{\text { Creative Commons }}$ Reconocimento 4.0. 


\section{Território Federal do Iguaçu}

O Território Federal do Iguaçu foi criado pelo Decreto-Lei lei n.5.812, de 13 de dezembro de 1943, durante o governo de Getúlio Vargas, e extinto, em 18 de setembro de 1946, pelas disposições da Constituição Federal de 1946. O referido Território abrangia uma área de 68,8 mil $\mathrm{Km}^{2}$, em terras do Oeste e Sudoeste do Paraná e o Oeste de Santa Catarina, sendo a maior parte deles pertencente ao estado do Paraná. Ao mesmo tempo em que era criado o Território Federal do Iguaçu, foi criada, também, através do Decreto 12.417 de 1943, a Colônia Nacional General Osório, cuja sede ficava em Francisco Beltrão, com o objetivo de promover a colonização ao longo da fronteira com a Argentina, na região de Barracão. A capital do Território foi, inicialmente, a cidade de Foz do Iguaçu, mas logo após a instalação do novo território, por razões de segurança, foi transferida para a cidade de Laranjeiras do Sul, que ficava mais afastada da fronteira. Por conta disso, seu nome foi alterado para Iguaçu. O traçado da fronteira do Território do Iguaçu também foi alterado, em 1944, para que pudesse incorporar também a região da nova capital. $\mathrm{O}$ contexto da criação do novo território foi a denominada Marcha para o Oeste, movimento nacionalista organizado durante o Governo Vargas, que defendia a ocupação efetiva das fronteiras brasileiras de Norte a Sul do país.

No entanto, a preocupação com esta região de fronteira já existia muito antes da criação do Território do Iguaçu. No final da Guerra do Paraguai (1864-1870), a fragilidade da ocupação brasileira desta região ficou muito evidenciada, uma vez que ela sempre foi uma espécie de região abandonada, tanto pelo governo federal como pelos governos estaduais do Paraná e de Santa Catarina. O controle brasileiro efetivo da região era tênue. Havia, no entorno de Foz do Iguaçu, grandes contingentes de indígenas e de grupos estrangeiros de várias nacionalidades, mas especialmente de paraguaios e argentinos, que não falavam português. As línguas correntes eram o guarani e o espanhol. O dinheiro circulante era o peso argentino e o guarani paraguaio. 
Atividades como a navegação do rio Paraná e a exploração da madeira e do mate eram controladas por argentinos.

Depois da Guerra do Paraguai, para reforçar a presença brasileira e defender os interesses nacionais nessa região, cogitou-se em criar uma Colônia Militar, na foz do Rio Iguaçu, providência que só veio a materializar-se em novembro de 1889. Essa Colônia Militar atuou até 1910, quando foi elevada à condição de Vila e tornou-se distrito de Guarapuava. Em 14 de março de 1914, foi criado o município de Vila Iguaçu e, em 1918, finalmente recebeu a denominação atual de Foz do Iguaçu. No final da década de 1930, Getúlio Vargas já demonstrava uma preocupação especial com a questão das fronteiras do Brasil com os países vizinhos, especialmente com a região da fronteira Oeste do Paraná e de Santa Catarina. A determinação de criar territórios federais nessas áreas estava presente na Constituição de 1937, mas só veio a concretizar-se em 1943. O Decreto que criava o Território Federal do Iguaçu também criava os territórios federais do Amapá, de Rio Branco, de Guaporé e de Ponta Porã. Durante sua curta existência, o Território Federal do Iguaçu teve dois governadores militares, João Garcez do Nascimento e Frederico Trotta.

Na década de 1960, ainda no espírito da "Marcha para o Oeste", que havia motivado a criação do Território Federal do Iguaçu, voltou a ideia e o movimento na região para criar o Estado do Iguaçu, abrangendo a área do antigo território, mas a proposta não teve força para concretizar-se.

\section{REFERENCIAS}

BURILlE, Celma F. de Souza. Nas Tramas da Separação: o caso do Estado do Iguaçu nas décadas de 1960 e 1990. (Dissertação de Mestrado). Curitiba: UFPR, 2010.

LOPES, Sérgio. O Território Federal do Iguaçu no contexto da "Marcha para o Oeste". Cascavel: Edunioeste, 2002.

RITT, Evaristo. A Colônia Militar de Foz do Iguaçu: um projeto de consolidação de uma Fronteira: 1880-1920. (Dissertação de Mestrado) Londrina: UEL, 2011. 